\title{
Quality of Life Evaluation by the Indigenous Population of the Arctic North of the Krasnoyarsk Territory (Krai) Based on Khatanga Rural Population
}

\author{
Vladimir I. Kirko ${ }^{1,2}$, Ekaterina A. Evseenko', \\ Ekaterina V. Malakhova ${ }^{1}$ and Aleksandr I. Shadrin ${ }^{1 *}$ \\ ${ }^{1}$ Krasnoyarsk State Pedagogical University \\ named after V.P. Astafyev \\ 89 Ada Lebedeva Str., Krasnoyarsk, 660049, Russia \\ ${ }^{2}$ Siberian Federal University \\ 79 Svobodny, Krasnoyarsk, 660041, Russia
}

The subject of the research is the quality of life of the small-numbered indigenous peoples of the Siberian North, the Nganasan and the Dolgans, locally resident in the territory of the rural settlement cluster in Khatanga District of the Taymyr (Dolgano-Nenets) Municipal District of the Krasnoyarsk Territory (Krai). The objective of the present research is to analyse the differentiation of quality of life perception by various strata of population living in the remote areas of the Northern Arctic zone of the Krasnoyarsk Territory (Krai). The purpose is to apply the comparative analysis method developed for the research of the quality of life of people living in the remote rural districts of the northern and Central taiga zones of Siberia. The main methodological base for the research is a group of theoretical scientific methods related to the analysis of empirical data obtained through questionnaires, surveys, observation and interview of small-numbered indigenous peoples in the places of their residence. The academic novelty of the research is the application of an efficient comprehension and evaluation method to the quality of life of the people compactly resident in severe northern climate, classified as smallnumbered indigenous peoples of the North. For differentiation of the population strata by the objective and subjective evaluation of their quality of life, statistic data were used; as a result, the degree of their satisfaction with the quality of education, security, local authorities, material welfare, cultural services, environmental situation and medical services was assessed.

Keywords: objectivity of quality of life, demographic indicators, socio-economic indicators, subjectivity of quality of life, northern territories, indigenous minorities, the quality of life, standards of living, welfare level, working conditions of the population.

(c) Siberian Federal University. All rights reserved

* Corresponding author E-mail address: director.nifti@mail.ru; katrinevseen@yandex.ru; malkaterok@mail.ru; shadrin1@kspu.ru

This work is licensed under a Creative Commons Attribution-NonCommercial 4.0 International License (CC BY-NC 4.0). 
The research is carried out within the framework of the regional contest of the Humanities and Social Sciences Department of the Russian Foundation of Fundamental Research "Power of Russia would grow with Siberia and the Arctic Ocean" 2017 - Krasnoyarsk Territory with the support of Krasnoyarsk Regional Autonomous Institution "Krasnoyarsk Regional Fund for Scientific and Technical Development Support. The project "Development and Reproduction of Human Capital as the Basis for Raising Quality of life of the SmallNumbered Indigenous Peoples of the North and Arctic of the Krasnoyarsk Territory (Krai) in the Conditions of Traditional Nature Use" No. 17-16-24004, in the framework of the project for fundamental scientific research of the year 2018 of the Federal State Budgetary Institution "Russian Foundation of Fundamental Research". Project "Anthropological, Medical and Psychological, Ethnical, Socioeconomic and Adaptive Factors, Influencing the Subjective Quality of life Perception and Human Capital Development of the Small-Numbered Indigenous Peoples of the Arctic Zone of the Krasnoyarsk Territory (Krai)” No. 18-49-243004.

Research area: social economic political and recreational geography, economic sociology and demography.

Citation: Kirko, V.I., Evseenko, E.A., Malakhova, E.V., Shadrin, A.I. (2018). Quality of life evaluation by the indigenous population of the Arctic North of the Krasnoyarsk Territory (Krai) based on Khatanga rural population. J. Sib. Fed. Univ. Humanit. soc. sci., 11(10), 15471571. DOI: 10.17516/1997-1370-0321.

\section{Introduction}

In accordance with the Sustainable Development Concept for the Small-Numbered Indigenous Peoples of the North, Siberia and the Far East, enacted by the Decree of the Government of the Russian Federation No. 132-p of February 4, 2009, its Implementation Plan for the years 2017-2025, Sustainable Development Concept for the Small-Numbered Indigenous Peoples of the Krasnoyarsk Territory (Krai) for the Years 2017-2025, approved by the Public Council of the Agency for Development of the Northern Territories and Support of the Small-Numbered Indigenous Peoples of the Krasnoyarsk Territory (Krai), the state assigns a special role to the resolution of the problems related to the preservation of the unique culture and improvement of the quality of life of the small-numbered indigenous peoples of the North and Siberia (including the Arctic) in the situation of active industrial exploration of the area.

\section{Theoretical framework}

Today, the quality of life evaluation has two main peculiarities: on one hand, it is obvious that objectivity in quality of life categories is the key factor for evaluation; on the other hand, one should understand that there is a relevant difference between the objective criteria and the subjective perception that may differ from each other in many aspects. Having analysed the methodological approaches to the quality of life 
evaluation (Naberezhnaia, 2008; Popova, Mikhaylova, 2016) we have revealed two main approaches:

1. Regulatory approach related to evaluation of the degree the legislative regulations, regional or municipal development programmes, allowance and subsidy programmes for population etc. are implemented (Bobkov, Maslovskiy-Mstislavskiy, 1994, 1998);

2. Economic-statistic, based on the attempts to build some integral synthetic evaluation and comparison indicators for the comparative analysis of the quality of life in different countries or regions based on the conceptual postulates similar to those of the "Human Development Index Calculation Method" suggested by the groups and specialists of the UN Development Programme (Ayvazian, 2012).

Sirgy, M. writes that the subjective quality of life aspects are: happiness, life satisfaction, subjective welfare (Sirgy, 2010). According to Savchenko, T.N. and Golovina, G.M., the "quality of life" category includes both objective and subjective components (Shishatskiy, Kirko, Keush, 2012). They understand subjective quality of life as a degree the axiological structures of various levels correspond to the ones perfect for the respondents (Egorova, Davydova, 2017).

Currently, one of the integral quality of life indicators used by the UN in its international comparative research, is the Human Development Index (HDI). This index is calculated on the basis of three indicators, i.e. life expectancy, gross domestic product per capita and education level. In her work "Methodological Approach to the Evaluation of the Quality of Life of the Regional Population", Medvedeva I.A. (Medvedeva, 2008) suggests to complement the mentioned factors with the social infrastructure, housing conditions, employment and personal security. Beliaeva L.A. (Beliaeva, 2009) comes up with a method that considers the objective and subjective quality of life evaluation with the index method (Kuleshov, 2013).

\section{Methods}

As an object for this study, villages of Khatanga cluster located in the NorthWestern part of the Taymyr (Dolgano-Nenets) Municipal District of the Krasnoyarsk Territory (Krai) were selected. As of beginning of 2013, in the territory of the cluster there were 135 acting enterprises, organizations, institutions, with 35 of them being municipal $(25.9 \%)$. In 2013 , the resident population of the settlement cluster was estimated as 5570 people, which is slightly lower than the number registered in 2012 ( $98.4 \%$ in relation to 2012), which was caused, first of all, by the population migration. $46 \%$ of the total population reside in the rural locality of Khatanga. 
The Taymyr (Dolgano-Nenets) Municipal District is a place of compact residence for the representatives of the following small-numbered indigenous peoples: the Dolgans, Nenets, Enets, Nganasans, Evenki. The sociocultural development level of their settlements in the territory of the region depend on the number of living standards indicators. As noticed by researchers (Vaysman, G.Z., Suliansziga, P.V., Tugolukova, V.A., Krivonogov, V.P., Isupov, V.A., Koptseva, N.P. (Amosov et al., 2012; Il'beykina et al., 2011, Kirko et al., 2017; Kistova, Koptseva, Pimenova, 2014; Koptseva, Kirko, 2014; Koptseva, Libakova, 2014; Pimenova, Koptseva, Seredkina, 2013), Reznikova, K.V. (Amosov et al., 2012; Il'beykina et al., 2011; Kistova et al., 2014; Zamaraeva et al., 2015, etc.), the essential indicators are: the population of the ethnocultural groups, the general condition of the healthcare and education systems and the traditional culture.

The studied settlement cluster consists of: the rural locality of Khatanga, Syndassko Village (population: 553 people, including 552 representatives of the smallnumbered indigenous peoples of the North (SNIPN), Zhdanikha Village (population: 192 people, including SNIPN: 188 people), Katyryk Village (population: 338 people, including SNIPN: 335 people), Popigai Village (population: 329 people, including SNIPN: 326 people), Novaya Village (population: 292 people, including SNIPN: 286 people), Kheta Village (population: 353 people, including SNIPN: 346 people), Kresty Village (population: 315 people, including SNIPN: 306 people, Novorybnaya Village (population: 612 people, including SNIPN: 609 people).

The territory of Khatanga settlement cluster (see Fig. 1) is inhabited by the following representatives of Northern ethnicities: the Dolgans: 3845 people, the Nganasans: 80 people, the Nenets: 8 people, the Evenki: 3 people, the Enets -1 person. The majority of the indigenous population resides in rural territories, occupied at the agricultural enterprises or in ethnic communities. The traditional economic activities are represented by 69 business units of various organizational and legal forms and forms of ownership, where 160 representatives of the small-numbered indigenous peoples are occupied. Altogether, 183 people are employed by agricultural organizations. The rural population is engaged in traditional economic activities, such as reindeer farming, hunting and fishing.

The purpose of the present paper is to study and analyse the differentiation of subjective perception of the quality of life by various strata of society resident in the remote settlements of the Northern Arctic zone of the Krasnoyarsk Territory (Krai). The specificity of the research is explained by the fact that the villages are mostly populated by the SNIPN. Similar researches, based on the method developed by the authors, have 
been carried out for the villages of Olenek, Zhilinda, Kharyialakh of Olenek District of the Republic of Sakha (Yakutia) (Kirko et al., 2017; Kuleshov, 2013) and the villages of Chindat and Pasechnoe (taiga zone) of Tyukhtet District of the Krasnoyarsk Territory (Krai) (Naberezhnaia, 2008; Kistova, Koptseva, Pimenova, 2014).

In the first case, the Arctic zone villages are the local residence of the Evenki, and in the second case the territory is the residence of the Chulyms. The results of the research of the socioeconomic and sociocultural condition of the small-numbered

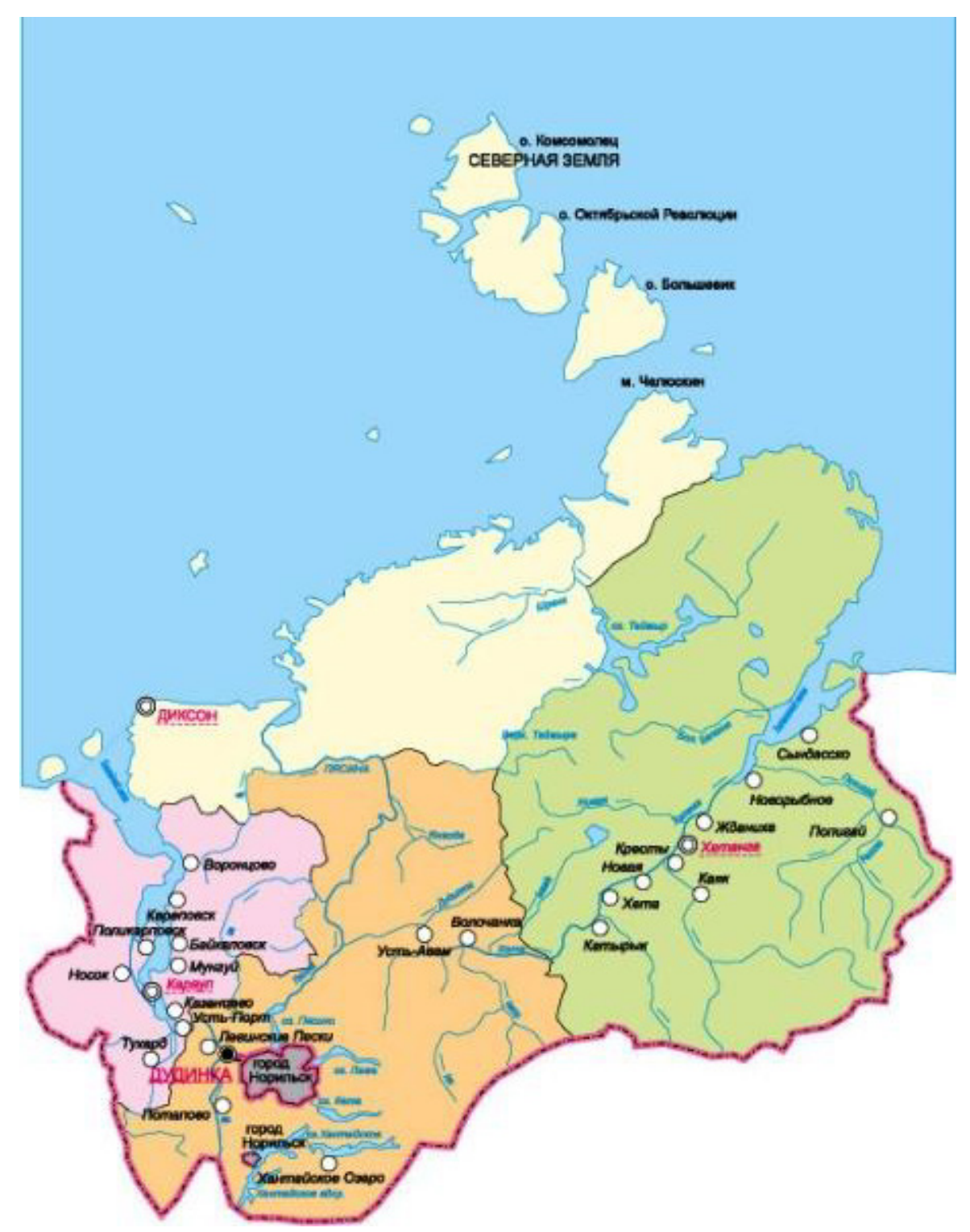

Fig. 1. Map of the Khatanga cluster, the Taymyr (Dolgano-Nenets) Municipal District of the Krasnoyarsk Territory (Krai) 
indigenous peoples of the North of the Krasnoyarsk Territory (Krai) are published in the works (Vasil'ev, 1976; Zamaraeva, 2014; Zamaraeva et al., 2015).

The most remote villages of Khatanga settlement cluster are Novorybnaya, Popigai and Syndassko. Almost the whole livestock of the domestic reindeer belongs to Tundrovik agricultural reindeer-breeding production cooperative (ARBPC) with the staff of 116 people. These villages are the concentration spots for the domestic reindeer herds with the livestock counting 6391 animal units.

Novorybnaya (see Fig. 2) is the largest village of the so-called "Northern cluster" in the territory, which also includes the villages of Zhdanikha, Syndassko and Popigai. It stands on the right, flatland side of the Khatanga River (from Evenki "big water", "much water"), almost right at the bay entrance, some way from the district centre. The distance from Dudinka to Novorybnaya is $849 \mathrm{~km}$; from Khatanga the distance is shorter, $165 \mathrm{~km}$. The present area of the village is around 3 sq.km.

The village was founded approximately in January 1931, though there are hardly any accurate data since the local archive was lost in the 1990-s. It is only known that the trading post founder was Mikhei Sotipatrovich Antonov, who also became the first chairman of Bludnovsky Nomad Council.

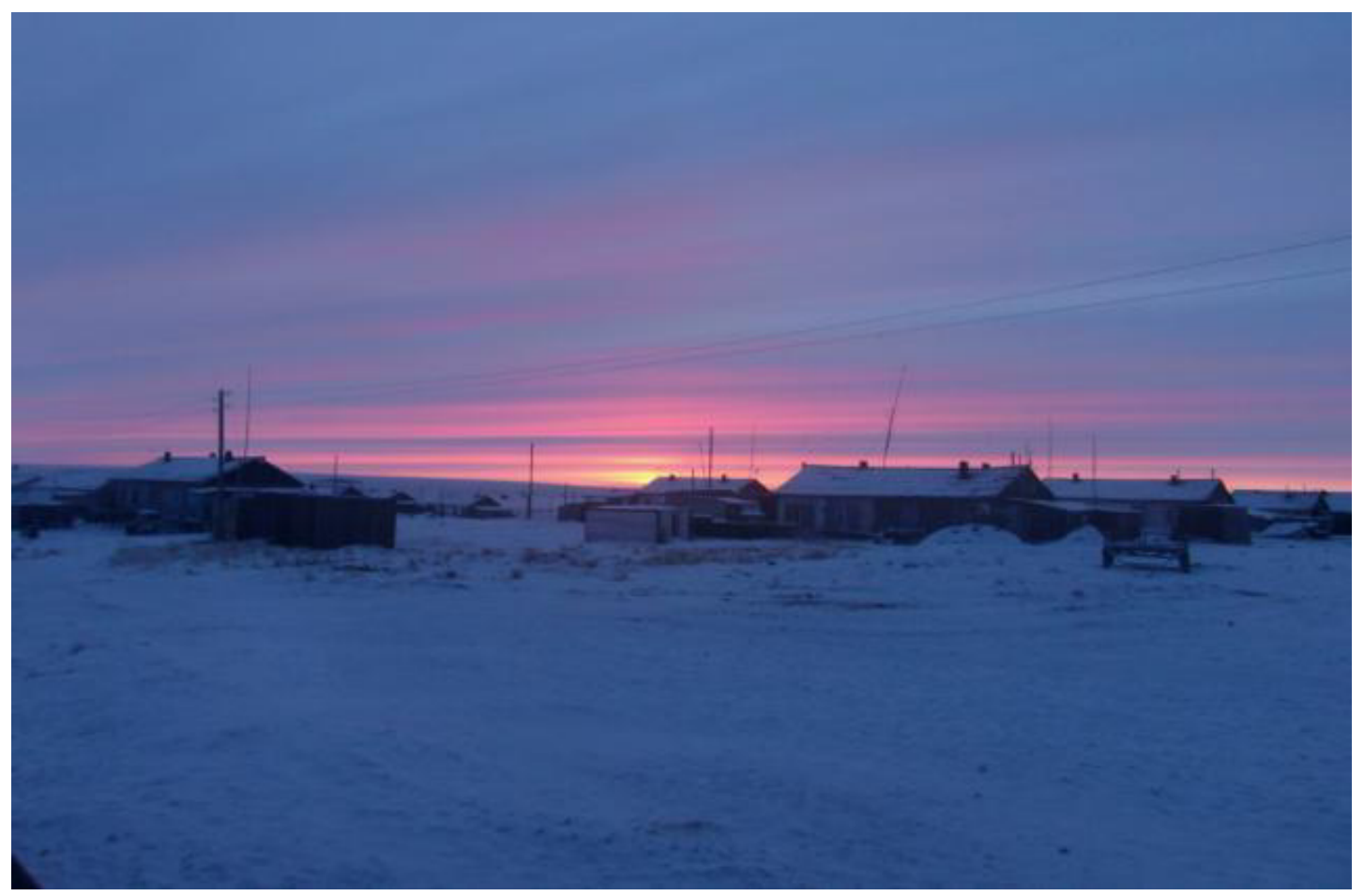

Fig. 2. Novorybnaya Village view 
As of October 1, 2014, the population of the village counted 561 people without the temporarily absent residents. The major part of the population is the Dolgans, representatives of a small-numbered indigenous people; besides, there are Russians, Kalmyks, Khakass, Nganasans, Evenki. The number of inhabitants aged from 0 to 18 years old is 180 people; 72 people are nomads, 107 people are retired, 32 people are physically disabled (including one child); 4 people are registered at the district centre employment service, 213 people are employed. The rest of the able-bodied population is students: 29 people.

Popigai is a village in the North-East, located in the territory of the famous Popigai Crater included into the UNESCO Geological Heritage List, on the right bank of the Popigai River (from Nganasan: "the forest river"), in front of the Rassokha River mouth. The distance to the district centre is considerable: it stands $325 \mathrm{~km}$ away. The crater was formed as a result of one of the greatest meteorite collisions. As a result, one of the richest and practically inexhaustible impact diamond deposit appeared.

Today, Popigai is a reindeer-breeding settlement with all required infrastructure: a diesel power plant, a rural health post, a school, a House of Culture (50 seats), a kindergarten. Even though the majority of population turned to sedentary lifestyle, traditional economic activities still exist. Moreover, such new activities as wild reindeer hunting and mammoth tusk collecting appeared. Just like in Novorybnaya, a great number of families (around 50) are nomads, spending the major part of the year in the tundra. Children stay at the care facility or join their parents, helping them in reindeer breeding, hunting or fishing.

Plant fossils in the crater, developed as a result of the largest collision of the meteorite with the Earth in history, virgin nature, unique hunting and fishing grounds can attract many tourists in the future.

Syndassko (or Syndaasko) Village is the Northernmost and the most remote from the district centre. It is located $285 \mathrm{~km}$ away from Khatanga and $100 \mathrm{~km}$ away from Novorybnaya; it is much closer to some settlements of the Republic of Sakha (Saskylakkh and Yuryung-Khaya). The village stands on the right bank of the Khatanga, where the river finds its way into the bay of the Arctic Ocean.

In all villages of Khatanga settlement cluster, there is a high percentage of multichild families. The demographic problem is out of question, since the birth rate is very high. The only unpleasant tendency is a large number of single mothers. Many women bring up 2-3 children born with different men. Their families help them to bring the children up. 


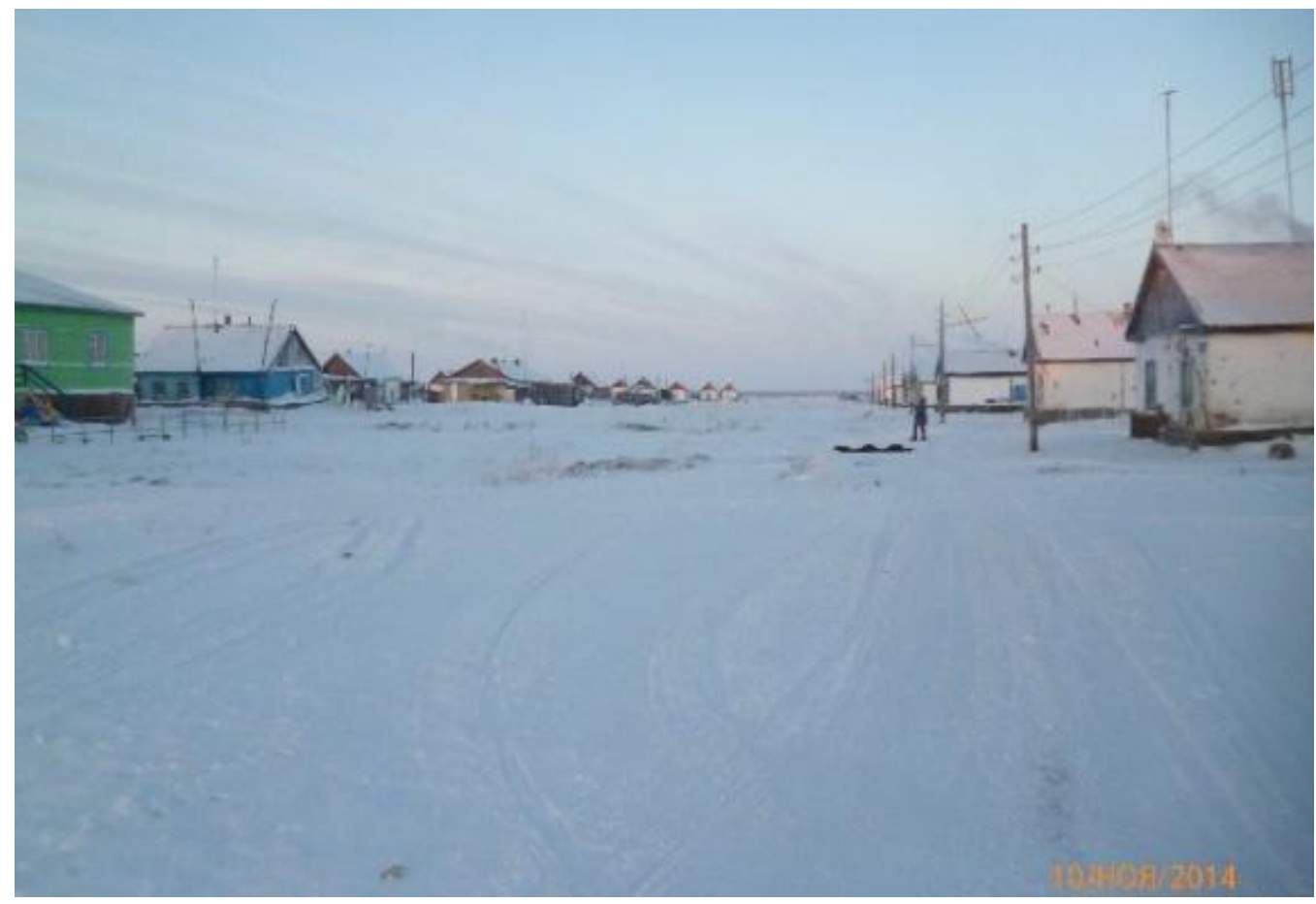

Fig. 3. Neighbourhood streets of Kresty Village

In Novorybnaya, Popigai, Syndassko and other villages of Khatanga there is a slight tendency of population decrease. It is related, first of all, to migration to cities (Dudinka, Norilsk) and the villages located closer to the district centre. Generally, the situation is not critical. The second reason is the death toll; the main causes of death are accidents (in the tundra or by the river), diseases etc.

The villages face a series of social problems associated with the falling number of SNIPN, insufficiency of healthcare and low living standards despite the development of traditional sector activities. The villages are in need for housing, which is currently in a poor shape. Many houses of the villages look large and awkward: in fact, those are mostly one-room structures surrounded by various extensions (see Fig. 3). Very often such houses are occupied by several families.

The present research was based on the method for determining the subjective perception of the quality of life by the residents of remote rural districts of the Arctic zones of Siberia (Evseenko et al., 2017; Kirko et al., 2017).

\section{Discussion}

The research was carried out in the village of Khatanga settlement cluster where small-numbered indigenous peoples of the North reside, such as: the rural locality of 


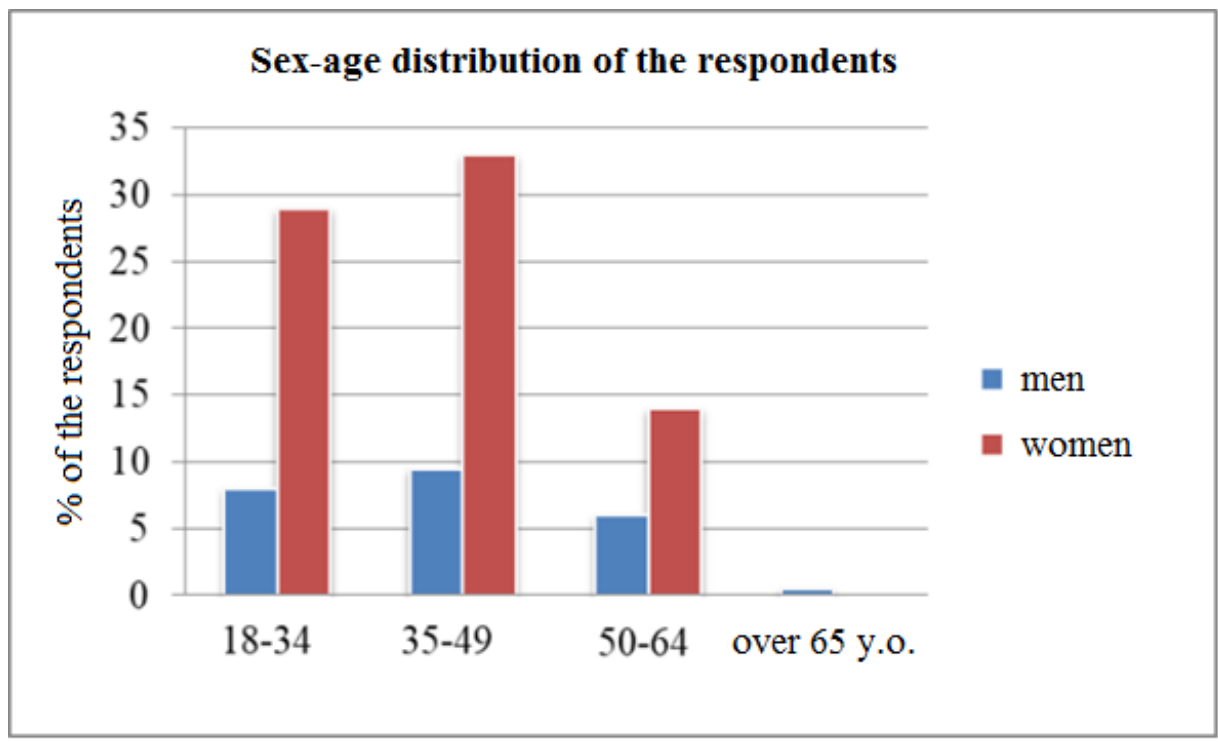

Fig. 4. Respondents' sex-age distribution diagram

Khatanga, the villages of Syndassko, Zhdanikha, Katyryk, Popigai, Novaya, Kheta, Kresty and Novorybnaya. The total number of respondents was 220 people resident in the villages and belonging to the SNIPN category, with $24 \%$ of men and $76 \%$ of women. The major age group of the respondents was 18-34 years old (37\%), 35-49 years old (42.5\%), 50-64 years old (20\%) and over 65 years old (0.5\%) (see Fig. 4).

Approximately $16 \%$ of the respondents have no completed secondary education, $33 \%$ of them finished secondary school, $34 \%$ have a vocational education, and $17 \%$ of the respondents have a complete higher education degree. Around $15 \%$ of the interviewed are unemployed, $5 \%$ are retired, $55 \%$ are worker-level employees, $18 \%$ are specialists in a certain field, $2 \%$ are individual entrepreneurs and 5\% hold management positions.

Speaking about the command of their mother tongue (ethnic language), 40\% confidently replied that they could read, write and count in it; $26 \%$ remarked they could speak their mother tongue, but not fluently, 24\% could exchange several phrases in their mother tongue but had poor literacy, and $10 \%$ of the interviewed replied they did not know their ethnic language at all (see Fig. 5).

During the analysis of labour conditions and employment rate of the local indigenous population (see Fig. 6), the following indicators were clarified and evaluated: employment type, workplace conditions, proximity of the workplace to the place of residence, occupation, salary, social guarantees and security. It is worthwhile mentioning that the employed respondents are mostly officially hired (92\%) or occupied at a budgetary or other municipal establishment (91\%). 


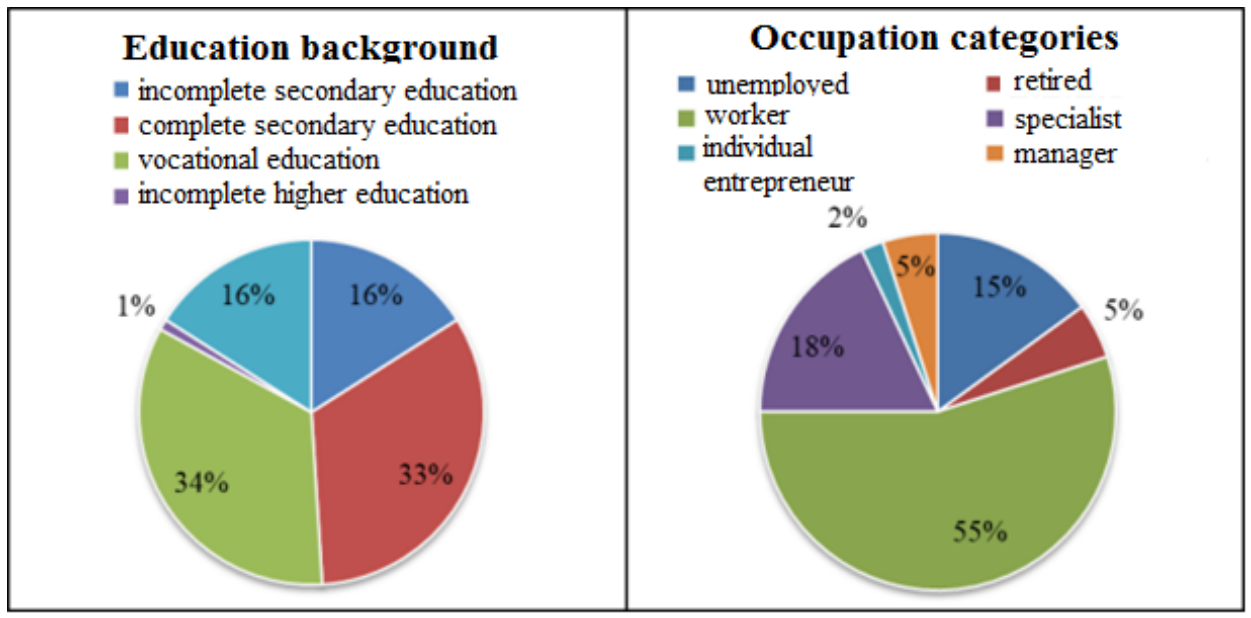

Fig. 5. Respondents' social differentiation diagram

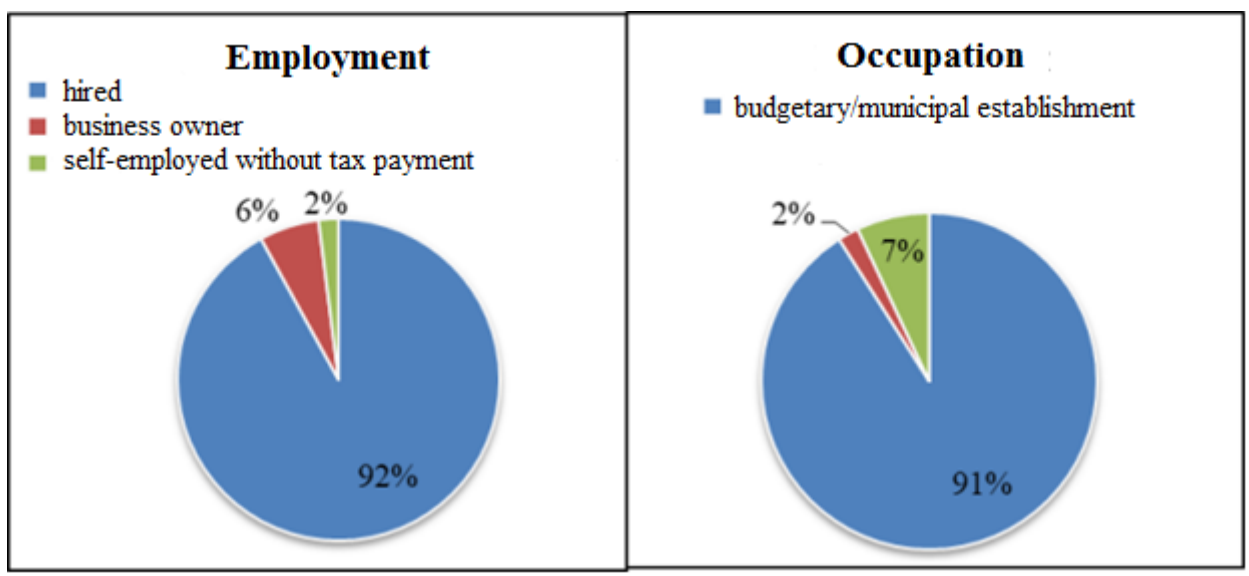

Fig. 6. Employment and occupation conditions of the respondents

Comparing the social guarantees and security categories, the domination of four main labour aspects for the Khatanga settlement cluster population was mentioned: the presence of all wage supplements $-74 \%$, a stable established wage $-59 \%$, an annual paid leave $51 \%$ of the respondents and a paid sick leave $-46 \%$ of the respondents. Such aspects as one-off bonuses or promotion opportunities did not get more than $20 \%$ of votes among the respondents. The wages of the local population are varied greatly: under 12000 RUR $15 \%$ of the respondents, $13000-15000$ RUR $-6 \%, 16000-20000-20 \%, 21000-30000$ RUR - 25\%, $31000-50000$ RUR - $21 \%$ and over 50000 RUR - 13\% of the respondents. The reason for such a variation is the different education background of the local population.

The data were analysed by calculating the arithmetic average of the values given in the individual questionnaires, where 3 meant the presence of a well-furnished 


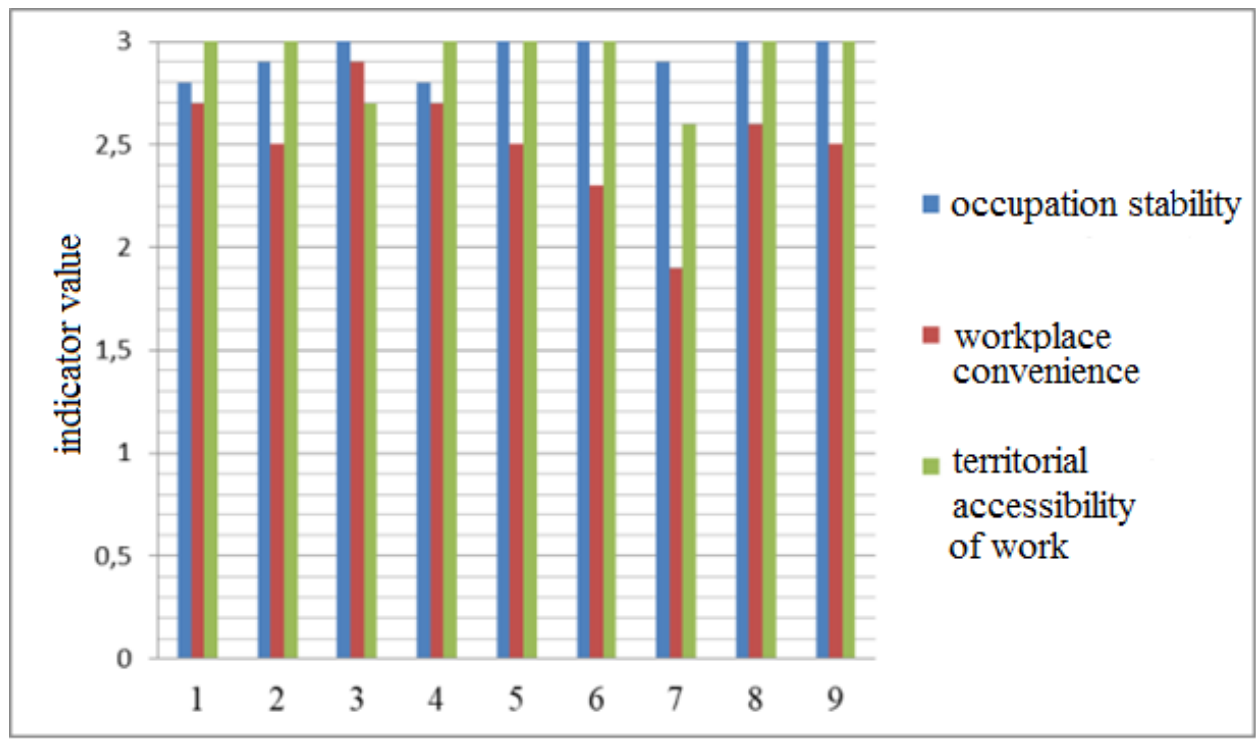

Fig. 7. Subjective perception of labour conditions and employment in the villages of Khatanga settlement cluster (1 - Zhdanikha Vil., 2 - Katyryk Vil., 3 - Kresty Vil., 4 - Novaya Vil., 5 - Novorybnaya Vil., 6 - Popigai Vil., 7 - Kheta Vil., 8 - Syndassko Vil., 9 - Khatanga rural locality)

own workplace and a geographically accessible places for employment, 2 meant the medium development level of the mentioned categories, i.e. no need for a separate workplace and relative accessibility of the places for employment, and 1 meant low level or absence of the abovementioned categories (see Fig. 7).

In the diagram above, the only outstanding aspects are the employment stability and workplace convenience. We see that the highest rates of the labour conditions, as subjectively evaluated by the indigenous peoples, are observed in the villages of Kresty and Syndassko, with Kheta having the lowest rate of all.

Evaluating the conditions of labour and employment, it is also worthwhile studying the recreation opportunities of the local population. The main criteria for this evaluation are: stability and regularity of holidays, granted holiday benefits, accessibility of recreation and healthcare facility near the place of residence. Generally, $87 \%$ of the respondents have an annual paid holiday leave; for $9 \%$, the leave is partially paid; $4 \%$ have no paid leaves due to employment peculiarities. In the average, $64 \%$ of respondents always enjoy the benefits of flight ticket cost reimbursement and discounted tour packages, $19 \%$ of respondents can afford such benefits very rarely and $18 \%$ have no opportunity to use the benefits. From the point of view of accessibility of recreation and rehabilitation facilities from Khatanga settlement cluster, $66 \%$ of 
respondents remark that their residence area is extremely remote and such facilities are accessible by air only; $23 \%$ suppose that such facilities are relatively far and can be reached by land, and $11 \%$ believe that there are some acceptable recreation and rehabilitation facilities close to their area of residence. The analysis of the obtained arithmetic average data was based on the same score scale: 3 scores for the high level of recreation and rehabilitation facilities, including the proximity of the facilities, a stable annual paid leave and granted benefits for flight ticket and tour package costs; 2 scores for a medium level, meaning a partially paid leave and benefits, as well as relative remoteness of the recreation and rehabilitation facilities, and 1 score for a low level of the mentioned categories or the absence of such. The arithmetic average value of each indicator reveals the difference in the recreation opportunities of the indigenous population of Khatanga settlement cluster (see Fig. 8).

In the diagram above we see a clear differentiation of the villages on the basis of perception of recreation and rehabilitation facilities, the stability of paid leaves and enjoyed holiday benefits. Obviously, the best conditions for recreation and rehabilitation are enjoyed by Popigai and Novaya Villages, and the worst are observed in Sybdassko, Zhdanikha and Khatanga.

Evaluating the infrastructure of the settlements, it was decided to emphasize the presence and functioning of such relevant categories as: cultural facilities (theatres,

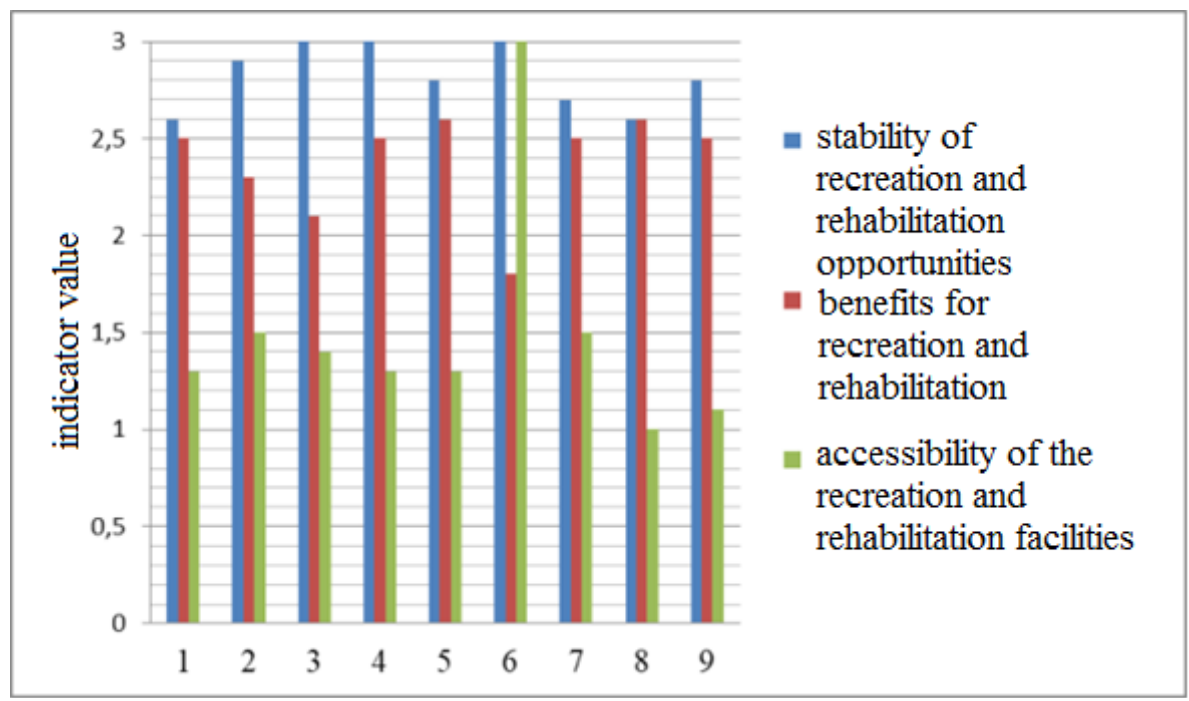

Fig. 8. Subjective perception of recreation and rehabilitation conditions around Khatanga settlement cluster (1 - Zhdanikha Vil., 2 - Katyryk Vil., 3 - Kresty Vil., 4 - Novaya Vil., 5 - Novorybnaya Vil., 6 - Popigai Vil., 7 - Kheta Vil., 8 - Syndassko Vil., 9 - Khatanga rural locality) 


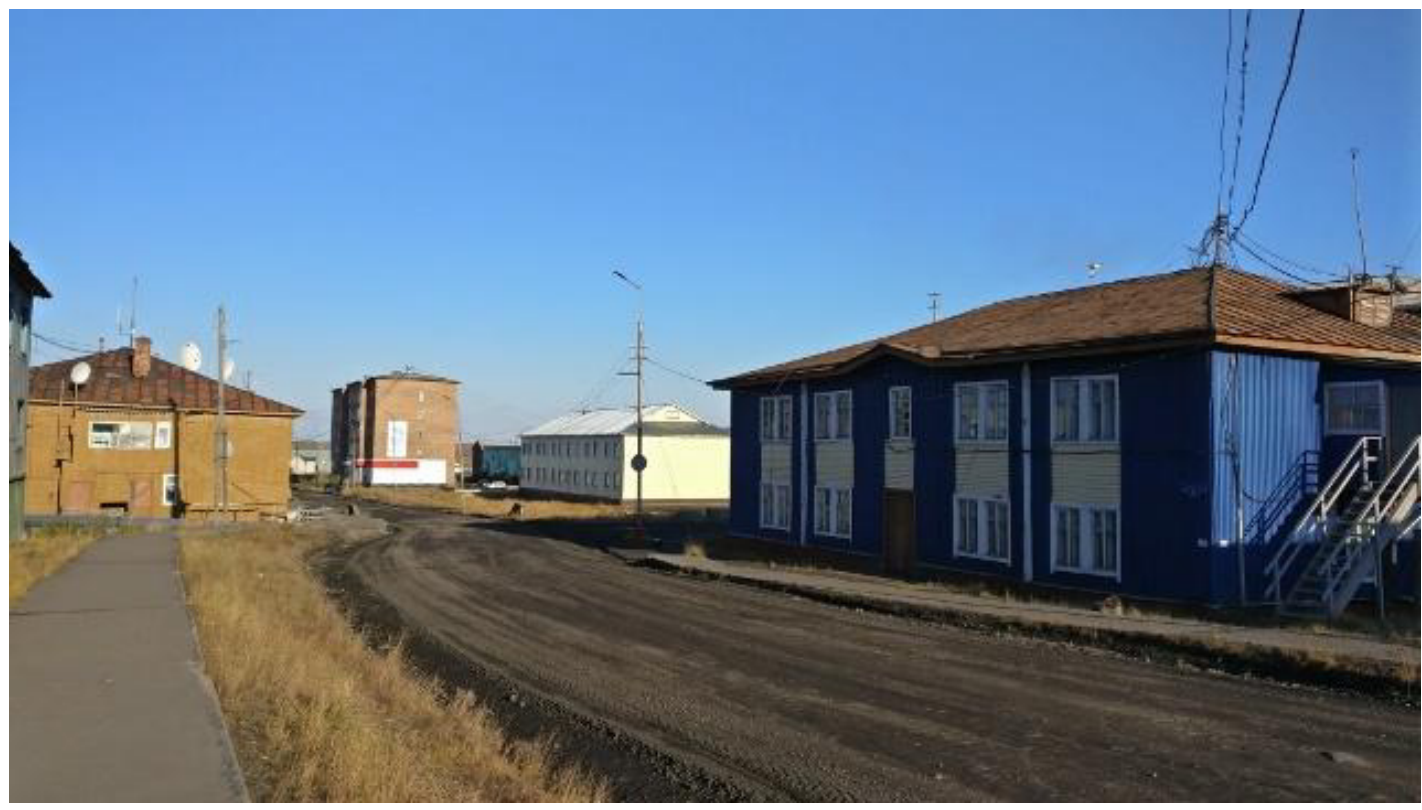

Fig. 9. Neighbourhood roads in the rural locality of Khatanga

museums, cinemas etc.), social facilities (schools, hospitals, health posts, pharmacies etc.), roads (see Fig. 9), the variety of available goods and territorial accessibility of shops.

Thus, in the process of analysis it was found out that the prevailing type of roads in Khatanga settlement cluster is self-rammed roads $-94 \%$ of the respondents; the shops are territorially accessible, but they provide a limited range of goods $-69 \%$ of respondents, cultural and social facilities are available and functioning $-73 \%$ of respondents for cultural and 97\% for social.

Taking a look at certain villages, the infrastructural differences between the Northern villages of the Krasnoyarsk Territory (Krai) hit the eye (see Fig. 10). The data were analysed by means of the arithmetic average of the values provided by the respondents in their individual questionnaires, where 3 scores meant full-scale functioning of the institutions, sufficient range of goods and proximity of shops, as well as urban-type quality roads; 2 scores meant a medium development level of such categories, i.e. the presence, but not sufficient functioning of the facilities, the developed rural type roads and proximity of shops with a limited range of goods, and 1 score meant a low development level or absence of the listed categories. From the diagram, we can see that great differences are observed between such categories, as cultural facilities, roads and shops.

In the diagram we see a minor mismatch in the subjective perception of roads and social facilities availability, unlike the categories of cultural facilities and shops. The 


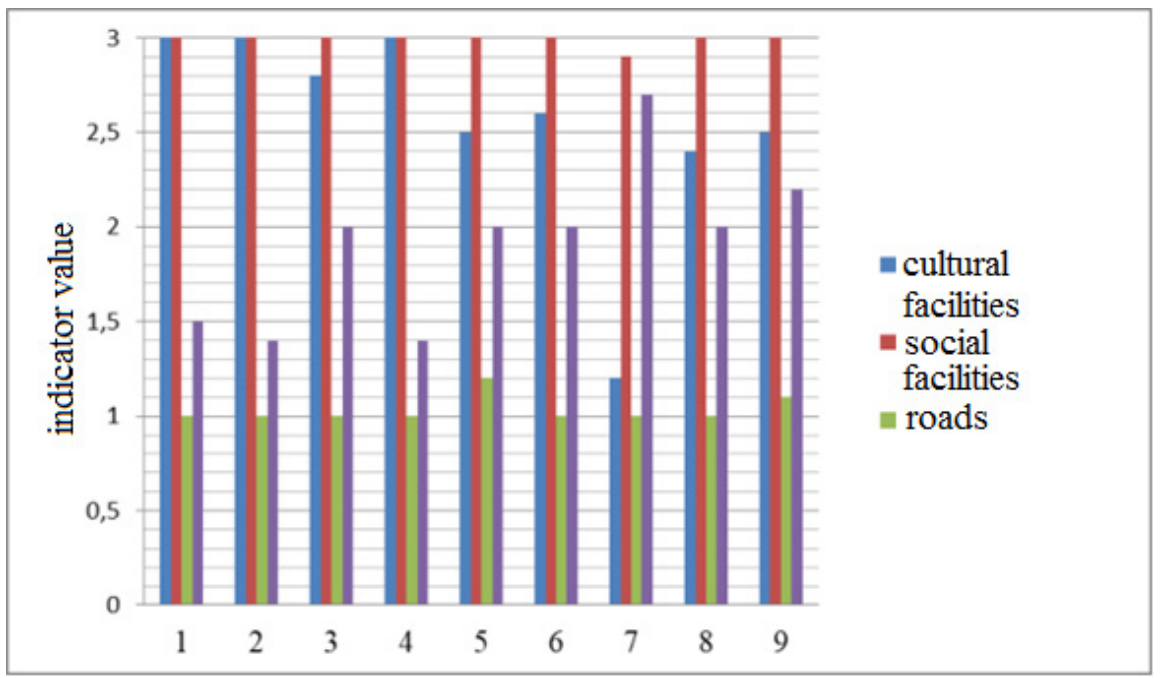

Fig. 10. Subjective perception of infrastructure in Khatanga settlement cluster (1 - Zhdanikha Vil., 2 - Katyryk Vil., 3 - Kresty Vil., 4 - Novaya Vil., 5 - Novorybnaya Vil., 6 - Popigai Vil., 7 - Kheta Vil., 8 - Syndassko Vil., 9 - Khatanga rural locality)

best infrastructure was found in the villages of Khatanga, Zhdanikha, Kresty, Popigai, and the lowest level of infrastructure was detected in Kheta Village.

In the evaluation of the Khatanga cluster population's everyday life perception, we included such categories as: lifestyle, traditional activities, presence of accommodation, living area per one resident, availability of housing utilities. For the whole group of villages it was found, that $83 \%$ of the respondents are sedentary, which confirms the high level of assimilation with the expatriate population and acceptance of a modern lifestyle; $10 \%$ of the respondents identify themselves as semi-nomad and $7 \%$ - as nomad. $54 \%$ of the respondents do not own an accommodation, but rent it or have it provided by their employer; $39 \%$ own some real estate and $7 \%$ have no accommodation at all. As for the subjective perception of sufficiency of the living area per resident, the majority of the respondents (45\%) remark severe deficiency of living space; $32 \%$ mention non-critical deficiency and $32 \%$ are satisfied with the size of their accommodation. Such results are explained by differences in the types of accommodation between the settlements, as well as the psychological peculiarities of perception. As for the housing utilities availability, $49 \%$ of respondents have no centralized supplies of water and electricity, which is also explained by the difference in their types of accommodation; $30 \%$ of respondents remark partial availability of housing utilities (electricity or water supplies), and $21 \%$ enjoy the centralized water and electricity supplies at their place of residence. The analysed arithmetic average 


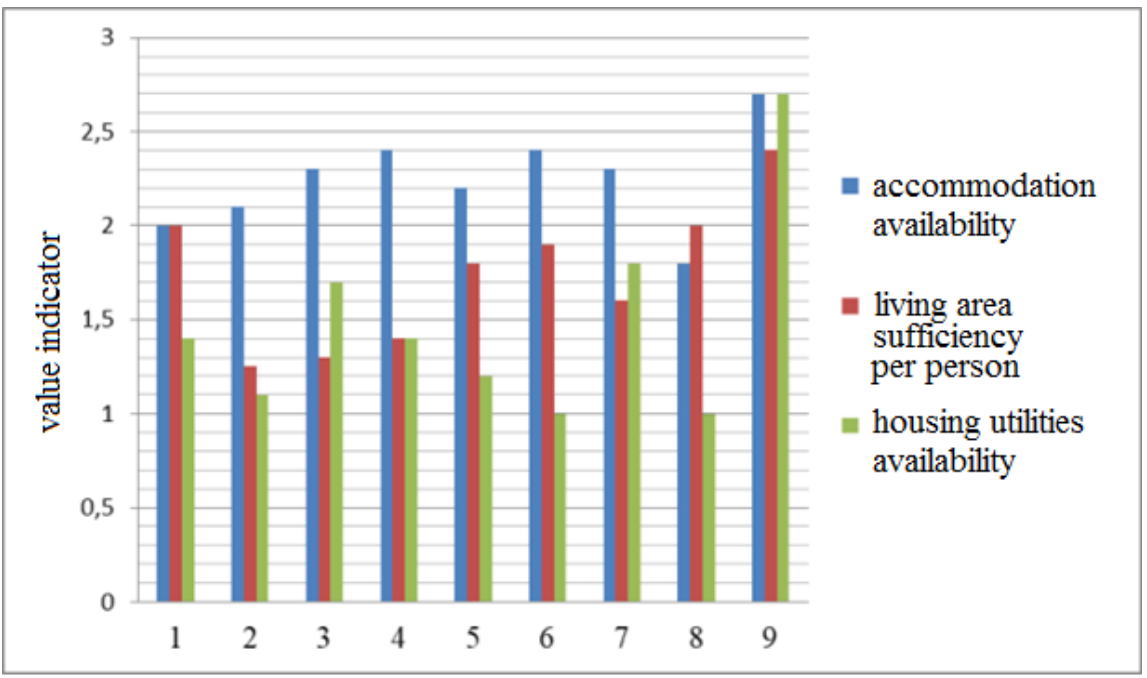

Fig. 11. Subjective evaluation of living conditions in Khatanga settlement cluster (1 - Zhdanikha Vil., 2 - Katyryk Vil., 3 - Kresty Vil., 4 - Novaya Vil., 5 - Novorybnaya Vil., 6 - Popigai Vil., 7 - Kheta Vil., 8 - Syndassko Vil., 9 - Khatanga rural locality)

of the scores provided by the indigenous population resident in Khatanga settlement cluser allowed us to carry out a correlative analysis of housing conditions in the villages (see Fig. 11).

Slight differences between the values are seen in the living area sufficiency and housing utilities availability. The greatest shares of owned accommodation are observed in the settlements of Khatanga, Novaya and Popigai, while the lowest values were found in Syndassko, Katyryk and Novorybnaya. The greatest values of centralized housing utilities availability are found in the settlements of Khatanga, Kheta and Kresty, and the lowest - to Popigai, Syndassko, and Katyryk. Therefore, the best subjective perception values were granted to the settlements of Khatanga and Kheta, while the worst were found in Syndassko and Katyryk Villages.

The level of satisfaction for each category can be calculated with the formula:

$$
\varepsilon=\frac{\left(\mathrm{N} 1^{+}+\mathrm{N} 2^{+}+\mathrm{N} 3^{+}\right)-\left(\mathrm{N} 2^{-}+\mathrm{N} 3^{-}\right)}{\left(\mathrm{N}-\mathrm{N} 1^{-}\right)}
$$

where $\mathrm{Ni}^{+}$is the number of respondents giving a positive answer, $\mathrm{Ni}^{-}$is the number of respondents giving a negative answer, and $\mathrm{N}^{-}$is the number of the undecided (Evseenko et al., 2017, 2018; Kirko, Evseenko et al., 2017; Kirko, Kuznetsova et al., 2017). The results were accumulated in the summary table (see Table 1). 
Table 1. Satisfaction with the quality of life (be categories and village)

\begin{tabular}{|c|c|c|c|c|c|}
\hline \multirow[b]{2}{*}{ Settlement } & \multicolumn{5}{|c|}{ Parameter $(\varepsilon)$} \\
\hline & $\begin{array}{c}\text { Labour and } \\
\text { employment } \\
\text { conditions }\end{array}$ & $\begin{array}{l}\text { Recreation and } \\
\text { rehabilitation } \\
\text { conditions }\end{array}$ & $\begin{array}{c}\text { Everyday life } \\
\text { conditions }\end{array}$ & Infrastructure & $\begin{array}{c}\text { Satisfaction } \\
(\varepsilon)\end{array}$ \\
\hline Zhdanikha Vil. & 0.7 & 0.4 & 0.2 & 0.4 & 0.4 \\
\hline Katyryk Vil. & 0.7 & 0.6 & 0.7 & 0.3 & 0.6 \\
\hline Kresty Vil. & 0.5 & 0.5 & 0.1 & 0.2 & 0.3 \\
\hline Novaya Vil. & 0.7 & 0.4 & 0.5 & 0.5 & 0.5 \\
\hline Novorybnaya Vil. & 0.8 & 0.4 & 0.4 & 0.5 & 0.5 \\
\hline Popigai Vil. & 0.6 & 0.3 & 0.2 & 0.2 & 0.3 \\
\hline Kheta Vil. & 0.6 & 0.3 & 0.3 & -0.02 & 0.3 \\
\hline Syndassko Vil. & 0.5 & 0.2 & 0.3 & 0.2 & 0.2 \\
\hline Khatanga rural locality & 0.9 & 0.1 & 0.6 & 0.6 & 0.5 \\
\hline Total value $\left(\varepsilon_{\mathrm{av}}\right)$ & 0.6 & 0.4 & 0.4 & 0.3 & 0.4 \\
\hline
\end{tabular}

Table 2. Quality of life satisfaction value (by categories)

\begin{tabular}{|l|c|}
\hline \multicolumn{1}{|c|}{ Parameter } & $\varepsilon$ \\
\hline Labour and employment conditions & 0.6 \\
\hline Recreation and rehabilitation conditions & 0.4 \\
\hline Everyday life conditions & 0.4 \\
\hline Infrastructure & 0.3 \\
\hline$\varepsilon_{\text {av. }}$ & 0.4 \\
\hline
\end{tabular}

The subjective perception of the quality of life of the indigenous people resident in the Khatanga group of settlements of the Taymyr Municipal District of the Krasnoyarsk Territory (Krai) revealed that the conditions for recreation and rehabilitation, everyday life and infrastructure are assessed as below average, which is interpreted as low satisfaction with the quality of life in the said settlements. Only labour and employment conditions are evaluated above average, which is explained with the stability provided by the availability of employment at municipal and budgetary establishments. The average satisfaction value of the indigenous population equals to 0.4 , which proves relative dissatisfaction of the population with the quality of life in the local settlements.

Even though the Taymyr District of the Krasnoyarsk Territory (Krai) is located in the extreme Northern area of the Arctic zone of Siberia, rich in various mineral resources that have attracted a great number of labour migrants to the new economic enterprises, the social and economic spheres are not functioning to the full due to deficiency of certain conditions, and traditional product manufacture also remains 


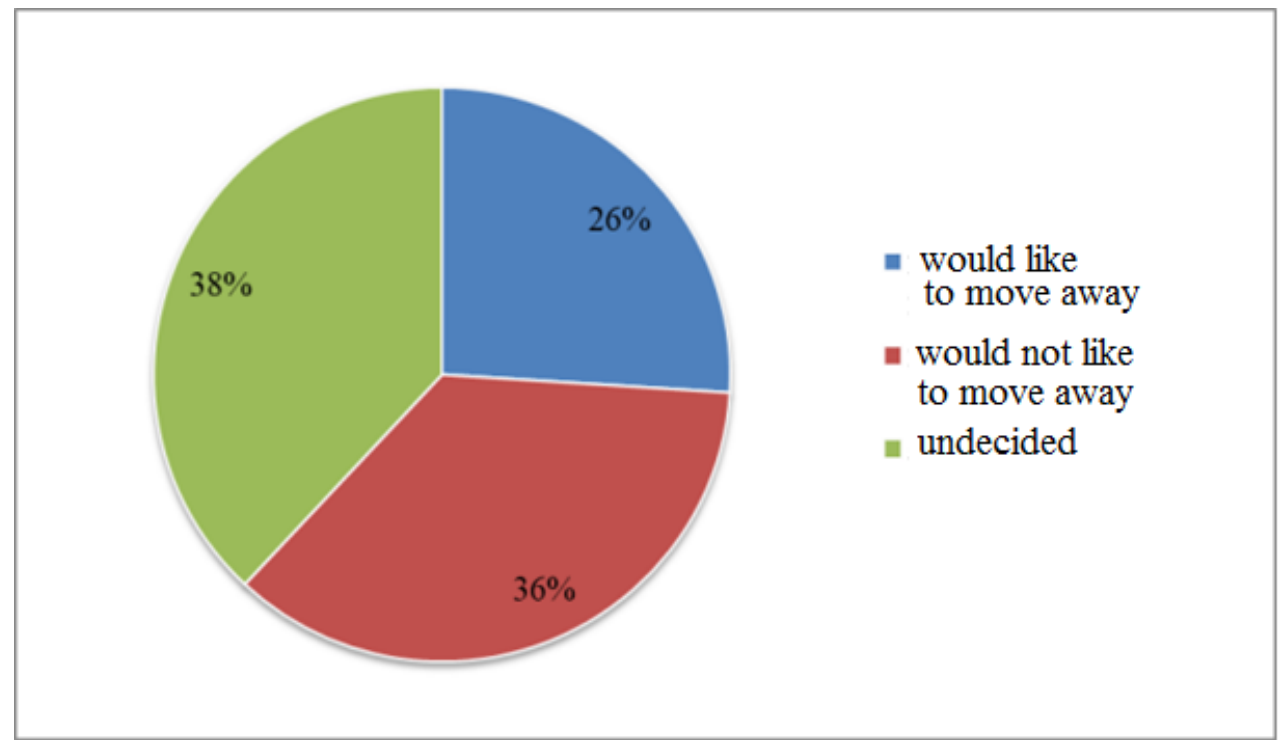

Fig. 12. Diagram of answers to the question on changing the place of residence

wasteful. However, the majority of residents would not like to move away (according to the sociological survey) (see Fig. 12).

\section{Results}

1. In Khatanga settlement cluster, there is a strong differentiation of population by the level of income due to the education and employment problems;

2. The labour conditions characterized with such indicators as stability and availability, are subjectively rated above average by the representatives of the indigenous people resident in the area of Khatanga settlement cluster, which is explained by the dominance of municipal and budgetary establishments in the labour market;

3. Recreation opportunities for the population are hard to access, and the free flight and discounted package tour benefits are hardly used by the local population due to some personal reasons or the lack of awareness of the benefits available to the SNIPN;

4. The subjective evaluation of the Khatanga cluster infrastructure by the local population reveals their dissatisfaction with the roads development degree and shop quality, along with the more than average satisfaction with the cultural and social facilities, due to the presence of new boarding schools, museums and houses of culture built within the framework of the indigenous Northern culture support programmes, as well as health posts and hospitals available to the business travellers and rotational employees working in the oil and gas industries; 
5. The subjective evaluation of the quality of life of the indigenous population of Khatanga settlement cluster of the Taymyr Municipal District of the Krasnoyarsk Territory (Krai) revealed that labour and employment, recreation and rehabilitation, everyday life and infrastructure conditions are rated below average, which proves the low satisfaction of the population with the quality of life. However, the majority of the respondents would not like to move away due to the habitualness of their lifestyle, love for the motherland and wish to stay closer to their families and friends.

\section{References}

Ayvazian, S.A. (2012). Analiz kachestva i obraza zhizni naseleniia (ekonometricheskiy podkhod) [Population Quality of Life and Lifestyle Analysis (Econometric Approach)]. Central Economic and Mathematical Institution of the Russian Academy of Sciences, Moscow, $402 \mathrm{p}$.

Amosov, A.E. (2010). Problemy zaniatosti korennogo naseleniia Krasnoiarskogo Severa (k80-letiiuobrazovaniia Taimyra iEvenkii) [Employment Problems of the Indigenous Population of the Krasnoyarsk North (in Commemoration of the $80^{\text {th }}$ Anniversary of Taymyr and Evenkia Foundation)]. A.E. Amosov. Krasnoyarsk: Bukva S., 176 p.

Amosov, A.E., Bokova, V.I., Zamaraeva, Iu.S., Il’beykina, M.I., Kirko, V.I., Kistova, A.V., Koptseva, N.P., Libakova, N.M., Luzan, V.S., Pimenova, N.N., Reznikova, K.V., Semenova, A.A., Sertakova, E.A. (2012). Korennye malochislennye narody Severa $i$ Sibiri $v$ usloviiakh global'nykh transformatsiy (na materiale Krasnoiarskogo kraia). Chast' 1. Kontseptual'naia i metodologicheskaia baza issledovaniia. Etnokul'turnaia dinamika korennykh malochislennykh narodov Krasnoiarskogo kraia [SmallNumbered Indigenous Peoples of the North and Siberia under the Conditions of Global Transformations (Based on the Krasnoyarsk Territory (Krai) Data. Part 1. Conceptual and Methodological Base for the Research. Ethnocultural Dynamics of the SmallNumbered Indigenous Peoples of the Krasnoyarsk Territory (Krai)]. Krasnoyarsk, Siberian Federal University.

Anisimov, A.F. (1963). Cosmological Concepts of the Peoples of the North. In Studies in Siberian Shamanism, 4, 157-229.

Arnesen, C.P. (2014). Protection of Traditional Cultural Expressions: an EU perspective. In Journal of Intellectual Property Law \& Practice, 9(5), 389-396.

Averin, A.N. (2005). Novye dannye o dinamike korennykh malochislennykh narodov Rossii [New Dynamic Data of the Small-Numbered Indigenous Peoples of Russia]. In Sotsiologicheskie issledovaniia, 2, 75-79. 
Beliaeva, L.A. (2009). Uroven' i kachestvo zhizni. Problemy izmereniia i interpretatsii [Living Standards and Quality of Life. Measurement and Interpretation Problems]. In Sotsiologicheskie issledovaniia [Sociological Research], 1, 33-42.

Benderskiy, Iu.G., Loginova, L.V., Matveev, A.M. (1998). Problemy sotsial'nogo razvitiia malochislennykh narodnostey Severa Evenkiyskogo avtonomnogo okruga (EAO), [Social Development Problems of the Small-Numbered Peoples of the North of the Evenkia Autonomous Okrug (EAO)]. In Zdorov'e obshchestva i bezopasnost' zhiznedeiatel'nosti: Materialy Vseros. nauch.-praktich. konf. [Health and Safety of the Society: Proceedings of the All-Russian Scientific and Practical Conference] Moscow, Klub "Realisty", 29-31.

Bobkov, V.N., Maslovskiy-Mstislavskiy, P.S. (1994). Dinamika urovnia zhizni naseleniia, [Living Standards Dynamics]. In Ekonomist [Economist], 6, 52-66.

Bobkov, V.N., Maslovskiy-Mstislavskiy, P.S. (1998). Kachestvo zhizni: kontseptsiia i izmerenie [Quality of Life: Concept and Measurement]. All-Russian Living Standards Centre, Moscow, $34 \mathrm{p}$.

Egorova, A.I., Davydova, V.Ia. (2017). Sub'ektivnaia otsenka kachestva zhizni trudosposobnogo naseleniia Zapadnoy ekonomicheskoy zony respubliki Sakha (Yakutiia) [Subjective Perception of the Quality of Life of the Able-Bodied Population of the Western Economic Zone of the Republic of Sakha (Yakutia)]. In Obshchestvo: sotsiologiia, psikhologiia, pedagogika [Society: Sociology, Psychology, Pedagogy], 12, 119-123.

Evseenko, E.A. (2016). Organizatsionno-ekonomicheskiy mekhanizm sovershenstvovaniia kachestva zhizni korennykh malochislennykh narodov Krasnoiarskogo kraia [Organizational and Economic Mechanism of the Quality of Life Improvement for the Small-Numbered Indigenous Peoples of the Krasnoyarsk Territory (Krai)]. In Geografia $i$ geoekologiia na sluzhbe nauki $i$ innovatsionnogo obrazovaniia. Materialy XI Mezhdunarodnoy nauchno-prakticheskoy konferentsii, posvyashchennoy Vsemirnomu Dniu Zemli i 100-letiiu zapovednoy sistemy Rossii [Geography and Geoecology at the Service of Science and Innovative Education. Proceedings of the XI International Scientific and Practical Conference Dedicated to the World Earth Day and the 100 th Anniversary of the Nature Reserves System of Russia], 136-138.

Evseenko, E.A., Kirko, V.I., Malakhova, E.V., Shadrin, A.I. (2017). Otsenka kachestva zhizni naselenia severa Krasnoiarskogo kraia na primere poselkov Tyukhtetskogo rayona - mest lokal'nogo prozhivaniia chulymtsev, otnosiashchikhsia 
k korennym malochislennym narodam Severa [Assessment of the Quality of Life of the Population of the North of the Krasnoayrsk Territory (Krai) Based on the Tyukhtet District Villages, Places of Local Residence of the Chulyms, a Small-Numbered Indigenous Ethnicity of the North]. In Sotsiodinamika [Sociodynamics], 8, 12-28.

Evseenko, E.A., Kirko, V.I., Malakhova, E.V., Shadrin, A.I. (2018). Sub'ektivnaia otsenka kachestva zhizni korennym naseleniem Severa Krasnoiarskogo kraia na primere Khatangskogo sel'skogo poseleniia [Subjective Quality of Life Perception of the Indigenous Population of the North of the Krasnoyarsk Territory (Krai) Based on Khatanga Rural Locality]. In Sotsiodinamika [Sociodynamics]. DOI: 10.25136/24097144.0.0.27074.

Gurban, I.A., Myzin, A.L. (2012). Sistemnaia diagnostika chelovecheskogo kapitala regionov Rossii: metodologicheskiy podkhod i rezul'taty otsenki [System Diagnostics of the Human Capital in the Regions of Russia: Methodological Approach and Evaluation Results]. In Ekonomika regiona [Regional Economy], 4, 32-39.

Il'beykina, M.I., Zamaraeva, Iu.S., Kistova, A.V., Koptseva, N.P., Libakova, N.M., Luzan, V.S., Nevol'ko, N.N., Pimenova, N.N., Reznikova, E.V., Semenova, A.A. (2011). Kul'tura korennykh malochislennykh narodov Severa v usloviiakh global'nykh transformatsiy [Culture of the Small-Numbered Indigenous Peoples of the North Under the Global Transformations]. Saint Petersburg, Eidos. 176 p.

Kirko, V.I., Evseenko, E.A., Malakhova, E.V., Koptseva N.P. (2017). Career Choices Made by Middle and High School Students with the Main Focus on Representatives of Indigenous Peoples of the North in the Republic of Sakha (Yakutia). In Vestnik Novosibirskogo gosudarstvennogo pedagogicheskogo universiteta [Novosibirsk State Pedagogical University Newsletter], 7(6), 7-25. DOI: 10.15293/2226-3365.1706.01.

Kirko, V.I., Keush, A.V., Shishatskiy, N.G. (2012). Problemy modernizatsii i innovatsionnogo razvitiia ekonomiki Severa [Problems of Modernization and Innovative Development of the Northern Economy]. In Materialy VI Mezhdunarodnogo foruma "Ot nauki k biznesu" 16-18 maia 2012 [Proceedings of the VI International Forum "From Science to Business", May 16-18, 2012]. Saint Petersburg, 100-103.

Kirko, V.I., Kuznetsova, IuS., Malakhova, E.V., Vasil'ev, E.A. (2017). Otsenka kachestva zhiznizhiteley arkticheskogo rayona Respubliki Sakha (Yakutiia) [Evaluation of the Quality of Life in the Arctic Area of the Republic of Sakha (Yakutia)]. In Severnye arkhivy i ekspeditsii [Northern Archives and Expeditions]. No.

Kistova, A., Pimenova, N., Zamaraeva, J., Reznikova, K. (2014). Research Possibilities for Studying the Indicators of Quality of Life of Indigenous Peoples of 
the North (Based on the Study of the Indigenous Peoples of the Russian North). In Life Science Journal, 11(6s), 593-600.

Kistova, A.V., Koptseva, N.P., Pimenova, N.N. (2014). Kul'tura detstva korennykh malochislennykh narodov Severa, Sibiri i Dal'nego Vostoka (na materiale polevykh issledovaniy chulymskoy etnokul'turnoy gruppy v TyukhtetskomrayoneKrasnoiarskogo kraia), [Childhood Culture of the Small-Numbered Indigenous Peoples of the North, Siberia and the Far East (Based on the Field Study of the Chulym Ethnocultural Group in Tyukhtet District of the Krasnoyarsk Territory (Krai)]. In Sovremennye problemy nauki i obrazovaniia [Current Problems of Science and Education], 1, 422.

Kolesnik, M.A. (2014). Obzor izucheniia fol'klora korennykh narodov Severa [Indigenous Northern Peoples' Folklore Studies Review]. In Litera, 3, 39-59. DOI: 10.7256/2409-8698.2014.3.13998.

Koptseva, N.P., Kirko, V.I. (2014). Specificity of Ethnogeny of the Indigenous Peoples of Central Siberia in the Transition from the Traditional to Modern Society. In Life Sci J., 11(7), 409-413.

Koptseva, N.P., Libakova, N.M. (2014). Gigiena kak kul'turno-antropologicheskaia praktika sokhraneniia i translyatsii kul'tury korennykh malochislennykh narodov Severa, Sibiri i Dal'nego Vostoka [Hygiene as a Cultural and Anthropological Practice of Preservation and Translation of the Culture of the Small-Numbered Indigenous Peoples of the North, Siberia and the Far East]. In Sovremennye problemy nauki $i$ obrazovaniia [Current Problems of Science and Education], 2, 646.

Kuleshov, A.V. (2013). Doklad glavy sel'skogo poseleniia Khatanga "Informatsiia ob osnovnykh itogakh sotsial'no-ekonomicheskogo razvitiia sel'skogo poseleniia Khatanga za 2013 god" [Report of the Head of Khatanga Rural Locality "Information on the General Results of the Socioeconomic Development of Khatanga Rural Locality for the Year 2013].

Libakova, N.M., Sertakova, E.A. (2018). Ekspeditsiia v poselok Surinda Evenkiyskogo munitsipal'nogo rayona. Dnevnik polevogo issledovaniia [Expdition to Surinda Village of Evenki Municipal District. Field Study Diaries]. In Severnye arkhivy i ekspeditsii [Northern Archives and Expeditions], 2(2), 6-29.

Luzan, V.S. (2014). Rol' biznes-sub'ektov v sotsial'no-kul'turnom razvitii korennykh malochislennykh narodov Rossiyskoy Federatsii [Role of Business Subjects in the Sociocultural Development of the Small-Numbered Indigenous Peoples of the Russian Fedderation]. In Sovremennye problemy nauki i obrazovaniia [Modern Problems of Science and Education], 4, 442. 
Maksimov, A.A. (2007). Realizatsiia interesov narodov Severa v usloviiakh promyshlennogo razvitiia: ot zarubezhnogo opyta $k$ rossiyskoy modeli [Putting the Interests of the Norhtern Peoples into Practics in the Situation of Industrial Development: from Foreign Experience to Russian Model], Syktyvkar, 136 p.

Medvedeva, I.A. (2008). Metodologicheskiy podkhod otsenki kachestva zhizni naseleniia regiona [Methodological Approach to the Evaluation of the Quality of Life of the Regional Population]. In Rossiyskoe predprinimatel'stvo [Russian Entrepreneurship], 9(1), 105-109.

Mulukaev, R.S. (2010). Istoricheskii opyt zashchity prav KMNS Rossii [Historical Experience of Protecting the Rights of the SNIPN of Russia]. In Istoriia gosudarstva $i$ prava [History of the State and Law], 3, 2-4.

Naberezhnaia, A. (2008). Ekonomiko-statisticheskaia otsenka urovnia zhizni naseleniia regiona [Economic-Statistic Evaluation of the Living Standards of the Regional Population]. In Regional'naya ekonomika: teoriia i praktika [Regional Economy: Theory and Practice], 12, 88-91.

Pimenova, N.N. (2014). Etnicheskaia situatsiia Krasnoiarskogo kraia: rol' kul'turnogo naslediia korennykh malochislennykh narodov [Ethnic Situation in the Krasnoyarsk Territory (Krai): Role of Cultural Heritage of the Small-Numbered Indigenous Peoples]. In Sovremennye problemy nauki i obrazovaniia [Current Problems of Science and Education], 4, 596.

Pimenova, N.N. (2014). Kul'turnoe nasledie korennykh malochislennykh narodov Krasnoiarskogo kraia i sovremennye kul'turnye praktiki [Cultural Heritage of the Small-Numbered Indigenous Peoples of the Krasnoyarsk Territory (Krai) and Contemporary Cultural Practices]. In Chelovek i kul'tura [Human and Culture], 2, 28-66. DOI: 10.7256/2306-1618.2014.2.11269.

Pimenova, N.N., Koptseva, N.P., Seredkina, N.N. (2013). Izuchenie dekorativnoprikladnogo iskusstva i traditsionnykh religiy korennykh malochislennykh narodov Severa kak faktor formirovaniia pozitivnoy obshcherossiyskoy kul'turnoy identichnosti [Studies of the Decorative and Applied Arts and Traditional Religions of the SmallNumbered Indigenous Peoples of the North as a Factor of Forming a Positive AllRussian Cultural Identity]. In Pedagogika iskusstva [Pedagogy of Arts], 2, 15-30.

Poppel, B. (2014). SLiCA, Survey of Living Conditions in the Arctic. In Encyclopedia of Quality of Life and Well-Being Research, 5993-6003.

Popova, L.N., Mikhaylova, A.V. (2016). Upravlenie faktorami povysheniia kachestva zhizni naseleniia (na primere arkticheskoy zony Rossiyskoy Federatsii) 
[Managing the Factors of Increasing the Quality of Life of the Population (Based on the Arctic Zone of the Russian Federation)]. In Fundamental'nye issledovaniia [Fundamental Research], 4(3), 662-667.

Pyzhova, Iu.A., Pyzhov, A.I. (2014). Otsenka urovnia sotsial'no-ekonomicheskogo blagopoluchiia korennykh malochislennykh narodov Krasnoiarskogo kraia [Evaluation of the Social and Economic Well-Being Level of the Small-Numbered Indigenous Peoples of the Krasnoyarsk Territory (Krai)]. In Issledovaniia molodykh uchenykh: otraslevaia i regional'naia ekonomika, innovatsii, finansy i sotsiologiia [Studies of Young Researchers: Industrial and Regional Economy, Innovations, Finance and Sociology] Novosobirsk, 240-244.

Savchenko, T.N., Golovina, G.M. (2006). Sub'ektivnoe kachestvo zhizni: podkhody, metody otsenki, prikladnye issledovaniia [Subjective Quality of Life Perception: Approaches, Evaluation Methods, Applied Research]. In Institut psikhologii RAN [Institute of Psychology of the RAS], Moscow, $170 \mathrm{p}$.

Seredkina, N.N. (2014). Etnicheskaia kartina mira v kontekste sovremennykh sotsial'nykh issledovaniy [Ethnic Picture of the World in the Context of the Current Social Research]. In Sotsiodinamika [Sociodynamics], 10, 26-59. DOI: 10.7256/23060158.2014.10.1344.

Shadrin, A.I. (2012). Kompleksnoe razvitie regiona na sovremennom etape (opyt mezhdistsiplinarnykh issledovaniy) [Comprehensive Development of the Region at the Present Stage (Interdisciplinary Research Experience)]. In Vestnik Krasnoiarskogo gosudarstvennogo agrarnogo universiteta [Krasnoyarsk State Agrarian University Newsletter], 4, 42.

Shishatskiy, N.G., Kirko, V.I., Keush, A.V. (2012). Sotsial'no-ekonomicheskie problemy sozdaniia territorii traditsionnogo prirodopol'zovaniia [Socioeconomic Problems of Creating a Traditional Nature Use Territory]. In Arktika i Sever [Arctic and North], 7, 178-185.

Sirgy, M.J. (2010). The Psychology of Quality of Life. Dordrech, Boston, London, Kluwer Academic Publishers, 611 p.

Sotsial'no-ekonomicheskoe razvitie sub'ektov Rossiyskoy Federatsii s territoriiami Arkticheskoy zony [Socioeconomic Development of the Constituent Entities of the Russian Federation with Arctic Territories] (2015). Available at: http://src-sakha.ru/wp-content/ uploads/2015/07/Analiticheskaya-zapiska-po-regionam-AZ-RF.pdf (accessed 8 July 2017).

Vasil'ev, V.I. (1976). Problemy etnogeneza i etnicheskoy istorii narodov Severa [Ethnogenesis and Ethnic History Problems of the Peoples of the North]. In Rasy $i$ narody [Races and Peoples], 6, 63. 
Zamaraeva, Iu.S. (2014). K voprosu o vozdeystvii global'nykh transformatsiy na korennye narody Severa, kompaktno prozhivaiushchie $\mathrm{v}$ regionakh Rossiyskoy Federatsii [To the Question on the Impact of the Global Transformations on the Indigenous Peoples of the North Compactly Resident in the Regions of the Russian Federation]. In Mezhdunarodnyy zhurnal prikladnykh i fundamental'nykh issledovaniy [International Applied and Fundamental Research Journal], 5(1), 113-116.

Zamaraeva, Iu.S., Kistova, A.V., Pimenova, N.N., Reznikova, K.V., Seredkina, N.N. (2015). Taymyr reindeer herding as a branch of the economy and a fundamental social identification practice for indigenous peoples of the Siberian Arctic. In Mediterranean Journal of Social Sciences, 6(3), 225-232.

\title{
Оценка качества жизни коренным населением
} Арктического Севера Красноярского края

\section{на примере Хатангского сельского поселения}

\author{
В.И. Кирко ${ }^{1,2}$, Е.А. Евсеенко ${ }^{1}$, \\ Е.В. Малахова ${ }^{1}$, А.И. Шадрин ${ }^{1}$ \\ ${ }^{1}$ Красноярский государственный педагогический \\ университет им. В.П. Астафьева \\ Россия, 660049, Красноярск, ул. Ады Лебедевой, 89 \\ ${ }^{2}$ Сибирский федеральньй университет \\ Россия, 660041, Красноярск, пр. Свободньй, 79
}

Предмет исследования - качество жизни коренных малочисленных народов севера Сибири - нганасанов и долган, локально проживающих на территории группь сельских поселений Хатангского района Таймырского (Долгано-Ненечкого) муниципального района Красноярского края. Целью настоящего исследования является анализ дифференциации субъективного восприятия качества жизни различными слоями населения, живущего в труднодоступных поселках северной арктической зоны Красноярского края. Задачей выступает применение разработанной методики сравнительного анализа качества жизни жителей в труднодоступных поселковых районах северной и иентральной таежной зоны Сибири. Основной методологической базой в данном исследовании выступает группа теоретических научных методов, связанных с анализом эмпирических данных в результате анкетирования, опроса, наблюдения и интервьюирования коренного малочисленного населения в местах их проживания. Научная новизна настоящего исследования заключается в применении эффективного метода понимания и оченки качества жизни населения, компактно проживающего в суровых северных условиях и относящихся к категории коренных малочисленных народов Севера. При определении дифференциачии различных слоев населения по объективной и субъективной оценке качества жизни были использованы данные статистики 
и выявлена степень удовлетворенности качеством образования; уровнем безопасности; деятельностью органов местного самоуправления; материальным благополучием; качеством предоставления услуг в сфере культуры; экологическим состоянием в районе и качеством медицинкого обслуживания.

Ключевые слова: объективность уровня жизни, демографические показатели, сочиально-экономические показатели, субъективность качества жизни, северные территории, коренные малочисленные народы, уровень жизни, уровень благосостояния, рабочие условия для населения.

Исследование выполнено в рамках регионального конкурса отделения гуманитарных и общественных наук РФФИ «Российское могущество прирастать будет Сибирью и Ледовитым океаном» 2017 - Красноярский край при поддержке КГАУ «Красноярский фонд поддержки научной и научно-технической деятельности». Проект «Развитие и воспроизводство человеческого капитала - основа для улучшения качества жизни коренных малочисленных народов Севера и Арктики Красноярского края в условиях традищионного природопользования» № 17-16-24004, а также в рамках проекта фундаментальных научных исследований 2018 года федерального государственного бюджетного учреждения «Российский фонд фундаментальных исследований». Проект «Антропологические, медико-психологические, этнические, сочиально-экономические и адаптивные факторы, влияющие на субъективное восприятие качества жизни и развитие человеческого капитала коренных малочисленных народов арктической зоны Красноярского края» № 18-49-243004.

Научная спещиальность: 25.00.24 - сочиальная экономическая политическая и рекреаиионная география, 22.00.03 - экономическая сочиология и демография. 